\title{
W POSZUKIWANIU
}

\section{NOWYCH KIERUNKÓW MOBILNOŚCI AKADEMICKIE): STUDENCI I UCZENI NEPALSCY W POLSCE}

\section{Anna Sadecka*}

Abstrakt

Celem artykułu jest przedstawienie zjawiska niezwykłej mobilności nepalskich studentów, badaczy i naukowców jako elementu szerszych procesów migracyjnych i tendencji społecznych charakterystycznych dla tego kraju. Kontekst stanowi wzmożony napływ Nepalczyków do uczelni polskich, między innymi w ramach projektów edukacyjnych Komisji Europejskiej Erasmus Mundus Akcja 2 w latach 2010-2016. Wykażę, że młodzi Nepalczycy poszukują coraz to nowych kierunków migracji w celach edukacyjnych.

Słowa kluczowe: mobilność akademicka, kultura migracji, Nepal, Erasmus

\section{LOOKING FOR NEW DIRECTIONS OF ACADEMIC MOBILITY: NePAlESE StUdentS AND ACADEMICS IN POLAND}

\begin{abstract}
The purpose of this paper is to present the phenomenon of extensive academic mobility among Nepalese students, researchers and academics as an element of wider migration practices and social processes in this country. The context for the analysis is active participation of the Nepalese in the European Commission educational programme Erasmus Mundus Action 2 and their visits to Polish universities in the years 2010-2016. The article will prove that Nepalese youth are searching for new destinations of academic mobility.
\end{abstract}

Keywords: academic mobility, migration culture, Nepal, Erasmus

*Mgr Anna Sadecka, Uniwersytet Warszawski, e-mail: anna.sadecka@adm.uw.edu.pl |ORCID: https://orcid.org/0000-0003-1567-6698 
Wprowadzenie

Celem artykułu jest przedstawienie zjawiska niezwykłej mobilności nepalskich studentów, badaczy i naukowcówjako elementu szerszych procesów migracyjnych i tendencji społecznych charakterystycznych dla tego kraju. Kontekst stanowi wzmożony napływ Nepalczyków do uczelni polskich, między innymi w ramach projektów edukacyjnych Komisji Europejskiej Erasmus Mundus Akcja 2 w latach 2010-2016. Praca stanowi część projektu badawczego, poświęconego analizie budowania kapitału kulturowego poprzez mobilność akademicką na przykładzie studentów i uczonych nepalskich w Polsce. Omówię w niej genezę kultury migracji w Nepalu i wpisujące się w nią zjawisko mobilności akademickiej, a także przedstawię refleksje samych stypendystów projektów Erasmus Mundus, którzy odwiedzili uczelnie polskie. Wykażę, że młodzi Nepalczycy poszukują coraz to nowych kierunków migracji wcelach edukacyjnych.

W ramach badań przeprowadziłam 26 wywiadów pogłębionych ze stypendystami projektów Erasmus Mundus z Nepalu kształcącymi się w Polsce w latach 2010-2016 oraz kilkoma studentami, którzy sami finansowali swoje studia. Dodatkowo, nawiązałam kontakt z koordynatorami wymiany na uczelniach polskich i nepalskich, kadrą zarządzająca na uniwersytetach nepalskich, badaczami z Nepalu na emigracji (na przykład w Wielkiej Brytanii i USA), przedstawicielami Komisji Europejskiej zajmującymi się programem Erasmus Mundus, pracownikami nepalskich firm rekruterskich, które oferują wyjazdy na studia zagraniczne. Zastosowałam szereg metod jakościowych: od wywiadów pogłębionych i rozmów, poprzez obserwację uczestniczącą, po analizę literatury i dokumentów. Ostatni etap tego przedsięwzięcia stanowiły badania terenowe w Nepalu w kwietniu 2017 roku, podczas których przeprowadziłam 11 wywiadów z absolwentami uczelni polskich w kilka lat po ich powrocie ze stypendium i udzieleniu pierwszego wywiadu 
(a zatem badania mają charakter podłużny). Ważna była dynamika i pewna ewolucja badań, uwarunkowana pozyskanymi danymi i wynikami analiz na kolejnych etapach. J ak wyjaśniają Hammersleyi Atkinson (1995, s. 35), „przygotowanie projektu badawczego powinno być procesem dynamicznym, odgrywającym niebagatelną rolę podczas wszystkich etapów badań".

Powstało już wiele prac i artykułów na temat zjawisk migracyjnych w społeczeństwie nepalskim oraz mobilności studentów. W Polsce przeprowadzono szereg badań dotyczących sytuacji studentów zagranicznych czy też udziału studentów w programach wymiany akademickiej (na przykład opracowania dotyczące programu Erasmus). Nie ma jednak zbyt wielu prac poruszających temat poszukiwania przez Nepalczyków nowych kierunków mobilności i migracji edukacyjnej, nie wspominając o wyborze Polski jako potencjalnego kraju docelowego. Zważywszy na to, że zjawiska teosiągają coraz to większe rozmiary, ich głębsza analiza wydajesię być uzasadniona.

Kultura migracji w Nepalu

Kultura migracji jest obecna w Nepalu od lat. W swoim artykule poświęconym mobilności studentów Mahendra Singh nazywa ją „wielowiekowym zjawiskiem” (2005). J eevan Raj Sharma (2011) dowodzi, że dla społeczności żyjących u podnóża Himalajów przemieszczanie się jest historycznie podstawową cechą przetrwania. Według tego autora, jest to jedna z kluczowych strategii pozwalających na przeżycie w tak trudnych warunkach społecznych, ekonomicznych, środowiskowych i politycznych. Dlatego też młodzi mężczyźni, a także coraz częściej i młode kobiety, masowo decydują się na migrację do dużych miast w Nepalu lub za granicę. Wyjazd może mieć na celu pracę, naukę, bądź też wiązać się z rekrutacją do wojska. Decyzje te w sposób oczywisty dotyczą nie tylko samych wyjeżdżających, ale także tych, których pozostawiają oni za 
sobą. Migracja staje się sposobem na życie orazjego składową częścią; prowadzi do poprawy sytuacji materialnej i rozwoju; ma wpływ na funkcjonowanie jednostek, poszczególnych gospodarstw domowych i całych społeczności. Kolejne pokolenia odwzorowują te zachowania i zjeszcze większą determinacją poszukują szans życiowych w dużych miastach nepalskich lub za granicą.

Dla mieszkańców wielu wiosek emigracja stała się kluczowym elementem kultury i gospodarki (Kharel 2016, s. 174). W tym kontekście możemy więc mówić o kulturze migracji ${ }^{1}$ (Sharma 2011). Kandel i Massey (2002) definiują kulturę migracji jako atmosferę panującą w danej kulturze, która skłania jej uczestników do wyjazdów. Według Syeda Ali (2007), który badał kulturę migracji w społeczności muzułmańskiej w Hyderabadzie (Indie), migracja staje się zachowaniem społecznym: ludzie uczą się aby migrować, a także kształtują w sobie potrzebę migrowania. Podobne zjawiska występują w społeczeństwie nepalskim.

J ak opisuje David Seddon (2005), historia migracji zarobkowej w Nepalu sięga początku XIX wieku, kiedy to głównie mężczyźni migrowali z terenów górskich na zachód, do Indii. Zaciągali się do wojska lub znajdowali zatrudnienie w służbie cywilnej; pracowali w kopalniach, fabrykach, na farmach, w hotelach i restauracjach, jako służący i strażnicy. Po podpisaniu porozumienia pomiędzy rządem Nepalu a Imperium Sikhijskim (1839), Nepalczycy wstępowali także do armii Sikhijskiej i wyjeżdżali do Pendżabu (Kharel 2016, s. 174). Ponieważ najczęstszym kierunkiem było miasto Lahore (ówczesna stolica Pendżabu), wyjeżdżający popularnie nazywani byli lahures. Do tej pory wyjeżdżający do pracy mogą być określani takim mianem (Seddon 2005; Kansakar 2003; Kharel 2016). Wielu spośród tych migrantów to znani z waleczności Gurkhowie. Na początku XIX wieku wstępowali oni licznie do armii

\footnotetext{
1 Według Jeffreya Cohena (2004, s. 5), o kulturze migracji możemy mówić wówczas, kiedy migracje są historycznie związane z daną społecznością (czyli są odnotowywane na przestrzeni wielu lat), stanowią element życia codziennego mieszkańców, oraz są akceptowane przez tę społeczność jako ścieżkę wiodącą do lepszej sytuacji ekonomicznej. Te wszystkie warunki są spełnione w przypadku Nepalu.
} 
indyjskiej, a po zakończeniu wojny brytyjsko-nepalskiej (przeciwko Brytyjskiej Kompanii Wschodnioindyjskiej w latach 1814-1816) służyli

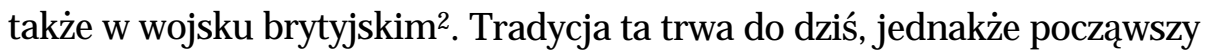
od lat 70. zeszłego wieku liczba Gurkhów w brytyjskim wojsku znacznie zmalała. Jak podaje Seddon (2005), w roku 2005 wynosiła ona około 3400 .

Liczne wyjazdy mężczyzn do Indii w celu wstąpienia do wojska pociągnęły za sobą fale migracji mężczyzn i kobiet w celach zarobkowych. Dodatkowo, dynamiczny rozwój plantacji herbaty windyjskich prowincjach Assam i Darjeeling spowodował wzmożony napływ robotników. Tworzyły się tam wówczas społeczności nepalskie. W Darjeelingu pojawiło się także zapotrzebowanie na porterów - Szerpów, pochodzących z dystryktu Solukhumbu - którzy udawali się na ekspedycje przeprawiające się przez Himalaje i Tybet.

W trakcie i po zakończeniu I wojny światowej odnotowano kolejny znaczny wzrost migracji z Nepalu do Indii w celach zarobkowych, który ponownie przybrał na sile podczas II wojny światowej. W roku 1951obalono rządy Rany, które skutecznie izolowały Nepal od reszty świata i do władzy doszedł król Tribhuvan z rodu Shah. W następnych latach wprowadzono szereg reform wspierających edukację i rozwój gospodarczospołeczny. Kraj coraz bardziej otwierał się na kontakty międzynarodowe. W latach 50. i 60. poprzedniego wieku nadal wielu Nepalczyków służyło w indyjskim wojsku, w policji i innych służbach. Według Seddona (2005), u schyłku dwudziestego wieku, około 250 tysięcy Nepalaczyków pracowało w sektorze publicznym w Indiach, z czego około 50 tysięcy służyło w wojsku. Autor przytacza dane Nepalskiego Instytutu Studiów Rozwoju (Nepal Institute for Development Studies), zgodnie

\footnotetext{
${ }^{2}$ Wojna zakończyła się przegraną Nepalu i podpisaniem Traktatu w Sagauli, jednakże Brytyjczycy byli pod tak wielkim wrażeniem waleczności Nepalczyków, że zaczęli tworzyć w swojej armii najemne regimenty składające się z Gurkhów. W kolejnych dekadach, aż do współczesnych czasów, oddziały te dzielnie walczyły przy boku Brytyjczyków.
} 
z którymi w roku 1997 ogółem około 750 tysięcy Nepalczyków znajdowało zatrudnienie w Indiach $w$ różnych sektorach przemysłu, w rolnictwie orazjako niewykwalifikowani robotnicy (Ibidem).

W roku 1985 rząd Nepalu wprowadził akt prawny, który regulował wjazdy za granicę w celach zarobkowych (tzw. Labour Act of 1985). Od tego czasu rozpoczęły się masowe emigracje do krajów Azji PołudniowoWschodniej i Zatoki Perskiej. Powstawały coraz to nowe agencje pośrednictwa pracy i prywatne firmy zajmujące się obsługą wyjeżdżających. Dzięki kontaktom ustanowionym przez Gurkhów, szukano także zatrudnienia w Hong Kongu, Singapurze i Wielkiej Brytanii.

W roku 1990 w Nepalu nastąpił zwrot w kierunku liberalizacji i wolnego rynku, co zachęciło tysiące Nepalczyków (zwłaszcza niewykwalifikowanych robotników) do wyjazdu do pracy, głównie do krajów Zatoki Perskiej. Innym popularnym kierunkiem stała się w tamtych czasach J aponia (w kolejnych latach emigracja do J aponii nasiliła się tak bardzo, że wroku 2015 Nepalczycy stanowili tam najliczniejszą społeczność z Azji Południowej $\left.{ }^{3}\right)$.

W roku 2001 rząd Malezji oficjalnie otworzył rynek pracy dla obywateli Nepalu i tylko w ciągu pierwszego roku wyjechało tam 85 tysięcy osób (Seddon 2005). Kolejnym istotnym czynnikiem, który wywołał falę dobrowolnej i przymusowej migracji Nepalczyków, była krwawa rewolucja Maoistów w latach 1996-2006. Tristan Bruslé (2010) dowodzi, że w tym czasie struktura emigracji z Nepalu, szczególnie jeśli chodzi o wybierane kierunki, uległa drastycznej zmianie. Na sile przybrały wyjazdy poza subkontynent indyjski: na Bliski Wschód, do Ameryki Północnej, do Australii, do Europy. Otworzyły się drogi dla wykwalifikowanych

\footnotetext{
3 Dipesh Kharel (2016) przedstawia przykład wioski w Zachodnim Nepalu (Malma), nazywanej przez lokalną społeczność „Małą Japonią”. Nazwa ta została nadana z powodu licznych wyjazdów mieszkańców wioski do Japonii, głównie do pracy w gastronomii. Według autora, na przestrzeni 10 lat (2005-2015), liczba Nepalczyków w Japonii wzrosła z 5314 do 55236.
} 
pracowników oraz dla młodzieży pragnącej zdobyć wykształcenie w krajach wysoko rozwiniętych.

Ostatnimi czasy dodatkowym impulsem do emigracji stało się katastrofalne trzęsienie ziemi w centralnej części Nepalu (w okolicach miejscowości Gorkha) w kwietniu 2015 roku.

Wraz z postępującą globalizacją, coraz więcej kobiet decydowało się na emigrację zarobkową. Głównie szukały one zatrudnienia w charakterze pomocy domowej w krajach Zatoki Perskiej. Ponieważ tego typu praca została zabroniona przez rząd nepalski, wiele kobiet wyjeżdżało nielegalnie, poprzez Indie. Łączyło się to zlicznymi problemami i zagrożeniami. Między innymi, można tu wymienić nielegalne zatrudnienie, brak praw podczas pobytu za granicą, oszustwa ze strony firm pośredniczących i pracodawców, przemoc, rozłąka z rodziną, zmniejszenie szans edukacyjnych i zawodowych dla pozostałych kobiet w rodzinie (na przykład sióstr i córek), które musiały zastępować je w czynnościach domowych (Bhadra 2007, s. 54).

Wiele mówi się o seksualnym wykorzystywaniu kobiet, porywaniu młodych dziewcząt i wywożeniu ich za granicę. Według raportu Narodów Zjednoczonych z 2003 roku, liczba dziewcząt wywożonych przez indyjską granicę wynosiła minimum 5000-8000 rocznie. Pomimo licznych problemów, Nepalki coraz chętniej wjeżdżają za granicę: raport Ministerstwa Pracy Nepalu podaje, że na przestrzeni lat 2008/9-2013/ 14 liczba kobiet emigrujących w celach zarobkowych (w danym roku) wzrosła z 8594 do 29 152. Dla porównania, liczba wjeżdżających mężczyzn wynosiła w tych samych latach odpowiednio 219956 i 521878 (Government of Nepal, Ministry of Labour and Employment, Department of Foreign Employment 2014, s. 21).

J eevan Raj Sharma (2011) opisuje ogromną skalę zjawiska emigracji we współczesnym Nepalu, a także rosnące aspiracje Nepalczyków, aby wyjeżdżać za granicę w różnych celach. Zgodnie z danymi zebranymi przez autora, prawie połowa gospodarstw domowych w Nepalu ma 
styczność z migracją: albo ktoś z rodziny wyemigrowal, albo ma w swoim gronie powracających z emigracji. Według spisu ludności z roku 2011, na przestrzeni lat 1991-2011 liczba Nepalczyków przebywających za granicą potroiła się: z 658290 wzrosła do 1921494, co stanowi ponad 7\% mieszkańców kraju (Government of Nepal, Ministry of Labour and Employment, Department of Foreign Employment 2014, s. 7).

Dla nepalskiej ekonomii wpływy z dochodów uzyskanych przez obywateli pracujących za granicą stanowią istotny zastrzyk finansowy: zarówno na poziomie ogólnokrajowym - stanowią oneok. 29\% produktu krajowego brutto Nepalu (Ibidem, s. 36), regionalnym, jak i dla poszczególnych gospodarstw domowych. Według Seddona (2005), obok rolnictwa i turystki, eksport siły roboczej to najważniejsze źródło utrzymania Nepalczyków.

Nie sposób nie zwrócić uwagi na olbrzymią skalę mobilności akademickiej Nepalczyków, która wyraźnie wzrosła wlatach 90 . XX wieku, a jeszcze bardziej nasiliła się wXXI wieku. Valentin (2014) twierdzi, żemłodzi ludzie uciekali przed wojną, perspektywą wcielenia do wojska, polityczną niestabilnością, słabością instytucji rządowych, bezrobociem. Wiele rodzin decyduje się na kierowanie dzieci na studia i staże zagraniczne, nawet jeżeli wiąże się to z wielkim wysiłkiem finansowym całej rodziny i koniecznością zaciągnięcia długu. Nic więc dziwnego, że podczas wywiadów słyszałam od praktycznie wszystkich przedstawicieli starszego pokolenia, że ich dzieci studiują lub pracują za granicą lub też planują wyjazd na studia do Stanów Zjednoczonych czy do Europy. Studia zagraniczne stały się znaczącym trendem, szczególnie wśród przedstawicieli klasy średniej (Ibidem).

Mobilność akademicka i jej kierunki

Instytut Statystyk UNESCO podaje, że w roku 2010 około 24 tysiące nepalskich studentów studiowało poza granicami swojego kraju. Zważywszy na liczbę mieszkańców Nepalu (niecałe 29 milionów), ogólną populację studentów w tym kraju (około 12\%) oraz fakt, że około jednej 
Czwartej społeczeństwa żyje poniżej granicy ubóstwa, liczby te wydają się być zaskakująco wysokie (UNESCO Institute of Statistics 2019).

Poniższy wykres 1. ilustruje to zjawisko. Jak widać, od lat 2012/ 13 do 2014/ 15liczba studentów nepalskich ubiegających się (wskali roku) o studia zagraniczne wzrosła z około 17 tysięcy do blisko 30 tysięcy.

Wykres 1. Liczba studentów nepalskich ubiegających się o wyjazd na studia zagraniczne

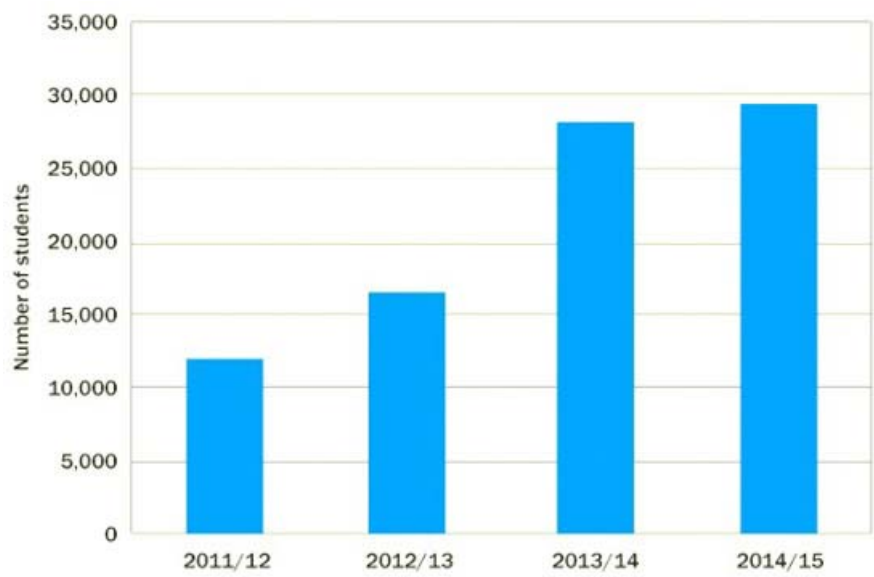

Źródło: ICEF 2015a.

Do czynników wypychających młodych ludzi na studia zagraniczne można zaliczyć niepewną sytuację polityczną w Nepalu, niestabilność gospodarki, niską jakość kształcenia i upolitycznienie uniwersytetów, brak dopasowania programów nauczania do wymogów rynku pracy, brak perspektyw na zdobycie pracy zgodnej z wykształceniem po ukończeniu studiów i przejrzystych zasad rekrutacji, komercjalizację szkolnictwa, uproszczenie przepisów emigracyjnych, tworzenie się nowej klasy średniej (Clark 2013; Valentin 2005, 2012, 2014). Czynniki zewnętrzne przyciągające młodych Nepalczyków do uczelni zagranicznych to między innymi tworzenie programów nauczania przeznaczonych dla studentów zagranicznych w krajach goszczących, powstawanie 
licznych programów stypendialnych, nacisk na umiędzynarodowienie uniwersytetów, rozwój komunikacji globalnej i mediów społecznościowych, czy wreszcie - wysoki rozwój społeczno-gospodarczy tych krajów.

Najczęściej wybieranymi kierunkami wyjazdów w celach edukacyjnych wśród Nepalczyków są Australia, J aponia, Indie, Wielka Brytania (Clark 2013, ICEF 2016). Według Yogesha Katiwada (2008), w roku 2007 studenci nepalscy plasowali się na trzynastym miejscu, jeśli chodzi o liczbę studentów zagranicznych w Stanach Zjednoczonych, a dla porównania, trzy lata wcześniej, przypadło im miejsce dwudzieste trzecie. Zgodnie z raportem Clarka (2013), w roku 2011 Nepalczycy znaleźli sięjuż na miejscu jedenastym. Liczba studentównepalskich przyjeżdżających do Stanów Zjednoczonych nieco spadła w kolejnych latach ze względu na zaostrzone przepisy wizowe.

Podobny wzrost można zauważyć wśród studentów nepalskich wybierających studia w Australii, J aponii i w Wielkiej Brytanii (Katiwada 2008). Raport organizacji International Consultants for Education and Fairs (ICEF) wykazuje, że nastąpił ogromny wzrost mobilności akademickiej Nepalczyków w latach 2013-2014 i dowodzi, że w tym czasie Nepal stał się trzecim co do wielkości rynkiem dla uczelni australijskich i drugim dla uczelni japońskich (ICEF 2015a).

Wydaje się, że uczelnie kontynentalnej Europy cieszą się mniejszym zainteresowaniem wśród Nepalczyków. J ednakże i tutaj w ostatnich latach odnotowano wyraźny wzrost napływu studentów z Nepalu. Według raportu ICEF dla Norwegii, w ciągu zalewie kilku lat liczba studentów nepalskich zwiększyła się ponad sześciokrotnie (roku W 2012 wynosiła ona 8,5\% całej populacji studentów kształcących się w Norwegii (ICEF 2015d). Kraj ten szczyci się szyblkim tempem internacjonalizacji szkół wyższych, co między innymi objawia się wysokim odsetkiem przyjmowanych studentów zagranicznych. 
Podobną strategię przyjęła Finlandia i również w tutaj liczba studentów przyjeżdżających z Nepalu jest bardzo wysoka: w roku 2015 była to trzecia co do liczebności grupa, po Chinach i Rosji (ICEF 2015c).

Karen Valentin (2014) zwraca uwagę na migrację nepalskich studentów do Danii na niespotykaną dotąd skalę. Obecnie jest to trzecia co do liczebności grupa studentów zagranicznych spoza Europy w Danii, pomimo, że po 2006 roku wprowadzono opłaty za studia dla studentów spoza Unii Europejskiej i krajów Europejskiego Obszaru Gospodarczego. Uczelnie szwedzkie oferują rozmaite programy stypendialne dla studentów z krajów rozwijających się, w tym z Nepalu, wykorzystując środki uniwersyteckie, unijne oraz rządowe. Dobrym przykładem były projekty Erasmus Mundus (z udziałem Uniwersytetów w Lund, Linkoping i Uppsali), program stypendialny dla Nepalczyków Uniwersytetu wUppsali (Uppsala Universitet b.r.) czy programy ogłoszone przez kilka uczelni z krajów europejskich w roku 2015, po trzęsieniu ziemi (allscholarshipdotnet 2016) w Nepalu.

Możemy się jednak spodziewać, że w najbliższym czasie nastąpi tendencja spadkowa wyjazdów do krajów nordyckich. Uczelnie norweskie rozważają wprowadzenie opłat za kształcenie, a Finlandia zdecydowała się na ten krok z początkiem roku 2016. Nieustannie dużą popularnością cieszą się studia w Niemczech, czego przykładem jest chociażby wzmożone zainteresowanie nauką języka niemieckiego wśród młodych Nepalczyków. J ak mówi niemiecki socjolingwista, profesor Urlich Ammon, im bardziej na wschód, tym bardziej ważny staje się jest język niemiecki (ICEF 2015b).

W ostatnich latach Nepalczycy zainteresowali się także krajami bałtyckimi i można zaobserwować coraz więcej ogłoszeń promujących studia na Litwie, Łotwie czy w Estonii. Niższe koszty utrzymania i czesnego, 
a przy tym relatywnie wysoki poziom nauczania, stanowią kluczowe czynniki przyciągające młodzież nepalską do tego regionu ${ }^{4}$.

Wykres 2. Liczba stypendystów Erasmus Mundus Akcja 2 na Uniwersytecie Warszawskim według kraju pochodzenia

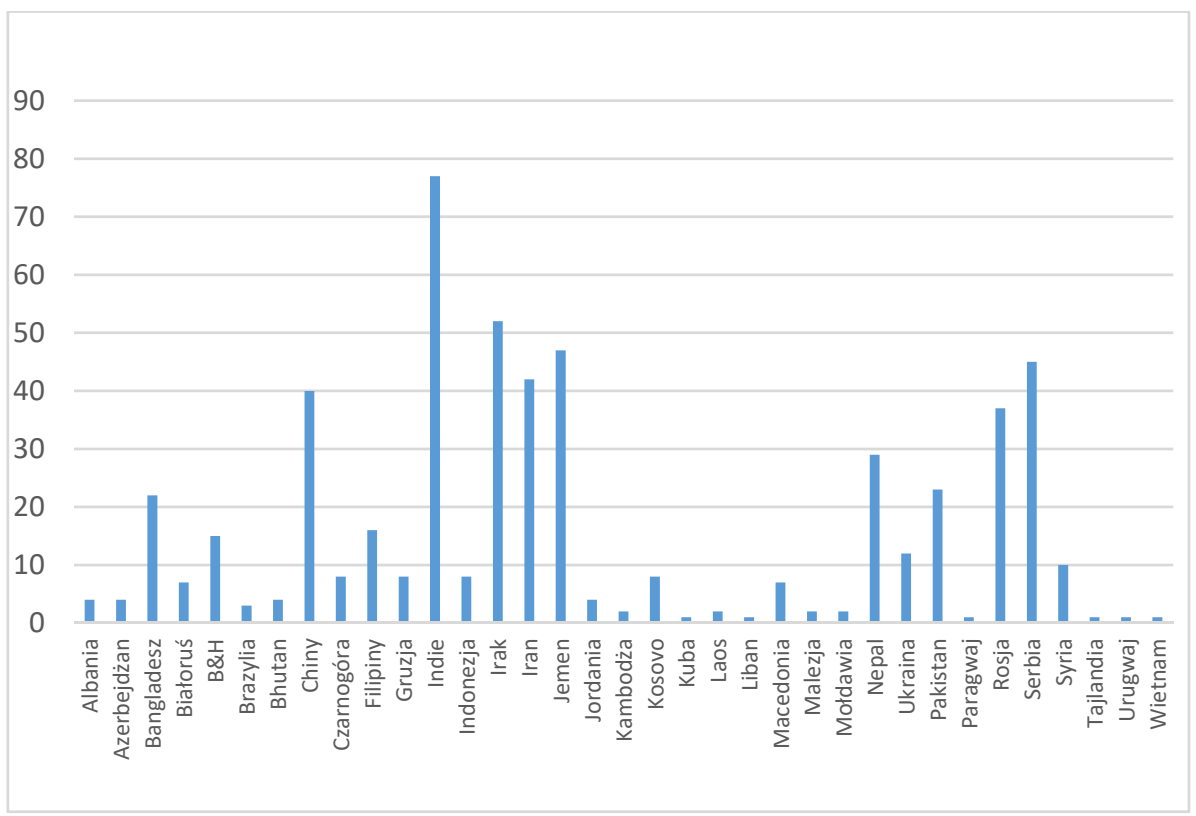

Źródło: Dane uzyskane z Biura Współpracy z Zagranicą Uniwersytetu Warszawskiego.

Polska nie zalicza się do szczególnie popularnych kierunków wybieranych przez studentów nepalskich, jednakżei tutaj można zauważyć tendencje wzrostowe. Co interesujące, w ostatnich latach można także zaobserwować napływ siły roboczej z tego kraju i znaczny wzrost liczby wydawanych pozwoleń na pracę (GUS 2018). Wydaje się, że niezmiernie ważnym czynnikiem umożliwiającym wyjazd na studia zagranicznie są dla

4 Na przykład w lutym 2017 roku przedstawiciele MSZ Estonii złożyli oficjalną wizytę w Nepalu. Poczyniono ustalenia na temat transferu technologii potrzebnych do zarządzania z zastosowaniem nowoczesnych rozwiązań informatycznych (e-Governance Academy b.r.). 
młodych Nepalczyków programy stypendialne, które zapewniają finansowanie studiów i badań naukowych, takie jak podawany już przykład programu Komisji Europejskiej Erasmus Mundus Akcja 2.

W przypadku polskich uczelni, udział w tym programie przyczynił się do rozwoju współpracy akademickiej z krajami poza unijnymi, w tym z Nepalem. Na przykład w latach 2008-2015 Nepalczycy stanowili ósmą co do liczebności grupę studentówi naukowców przyjeżdżających na Uniwersytet Warszawski w ramach projektów Erasmus Mundus Akcja 2.

Czynniki warunkujące wybór kierunku mobilności akademickiej

Według J eevana Raj Sharmy (2011), migracja w celach edukacyjnych, szczególnie do odległych krajów, nie jest dostępna dla wszystkich $\mathrm{Ne}$ palczyków. Wynika to z faktu, że tylko nieliczni młodzi ludzie posiadają wystarczające zasoby finansowe, powiązania społecznei polityczne, aby móc podjąć takie wyzwanie. Wybór kierunku migracji kształtowany jest przez wiele czynników, w tym przez status społeczno-ekonomiczny, położenie geograficzne rodzinnej miejscowości, posiadany kapitał kulturowy.

Yogendra Bahadur Gurung (2008) dowodzi, że istnieje korelacja pomiędzy pozycją społeczną, a wyborem kierunku migracji: członkowie bogatszych gospodarstw domowych częściej migrują do miast nepalskich i za granicę, biedniejsi przeważnie przemieszczają się do innych obszarów rolniczych w Nepalu i do Indii. Autor podkreśla, że w Nepalu kasta i kategoria etniczna mają wpływ na posiadany kapitał kulturowy oraz na dynamikę wykluczenia społecznego. Stawia on następujące hipotezy: (1) grupy dominujące w społeczeństwie nepalskim są również dominujące w migracjach i migrują w miejsca bardziej odległe, stwarzające większe możliwości; (2) grupy wykluczone ze społeczeństwa nepalskiego także migrują, ale wybierają destynacje bliższe, które nie wymagają dużych nakładów finansowych i wiążą się z niższym ryzykiem. 
Gurung potwierdza obie hipotezy, ale jednocześnie przekonuje, że istotną rolę odgrywają powiązania społeczne i historyczne. Na przykład mieszkańcy terenów górskich są zazwyczaj bardziej mobilni niż przedstawiciele tych samych grup społecznych z innych regionów Nepalu i wybierają kierunki, które w oczach Nepalczyków dają relatywnie większe możliwości. Można przypuszczać, że zjawisko to związane jest z tradycją wstępowania do indyjskiego lub brytyjskiego wojska. Muzułmanie, którzy należą do grup wykluczonych społecznie, także migrują do odległych krajów, ale zazwyczaj są to miejsca powiązane z ich religią i kulturą - na przykład Malezja i kraje Zatoki Perskiej.

Badanie Fafchamps i Shilpi (2011) dostarcza danych, które jasno dowodzą, że w Nepalu najbardziej mobilni są przedstawiciele najwyższych warstw społecznych: Brahmini stanowią 34,5\% wszystkich emigrantów, Chetri - 21,5\%, Newarzy - 7,4\%. Można przypuszczać, że wśród migrantów wyjeżdżających w celach edukacyjnych udział tych grup będzie jeszcze wyższy. Zaliczali się do nich wszyscy stypendyści Erasmus Mundus, którzy przyjechali do Polski. Dodatkowo, wywodzili się oni z najbogatszych obszarów Nepalu, czyli Doliny Kathmandu i Teraju.

Karen Valentin sugeruje, że studia zagraniczne są przywilejem nepalskiej klasy średniej, osadzonej głównie w stolicy kraju. Badaczka wykazuje, że istnieje hierarchia kierunków wyjazdów w celach edukacyjnych, która odzwierciedla postrzeganie przez Nepalczyków szans i możliwości, jakie niesie ze sobą pobyt w danym kraju. I tak, na najniższej pozycji stawiane są Indie, w środku - Daleki i Bliski Wschód, a z najwyższym statusem wiąże się migracja do Europy, Australii i Ameryki Północnej (Valentin 2014).

Metoda badań

Moje badania nad losami nepalskich studentów i naukowców kształcących się w Polsce trwały przeszło 5 lat. Punktem wyjściowym był przyjazd 
8-osobowej grupy Nepalczyków do uczelni polskich w ramach projektów Komisji Europejskiej Erasmus Mundus Akcja 2 jesienią 2010 roku. Na ponad 30 stypendystów z Nepalu, w ramach wszystkich takich projektów nawiązałam bliższy kontakt z 22 osobami. J ednocześnie, w celu uzupełnienia obrazu, poszukiwałam kontaktów z innymi Nepalczykami studiującymi w Polsce. W sumie na tym etapie badań przeprowadziłam 26 wywiadów: 4 ze studentami na poziomie licencjackim, 11 ze studentami na poziomie magisterskim, $5 \mathrm{z}$ doktorantami, 2 z naukowcami po doktoracie, 3 z pracownikami naukowymi i 1 z pracownikiem administracyjnym. Większość z nich pochodzi z najwyższej kasty Braminów (16 osób), a pozostali - zinnych uprzywilejowanych kast: Chetri i Newar (odpowiednio 7 i 3 osoby). Wśród wszystkich badanych znalazło się tylko 5 kobiet.

Proporcje te zbliżone są do proporcji stypendystek z Nepalu w całym programie Erasmus Mundus: raport Erasmus Mundus Action 2 Impact Survey, Results dowodzi, że w latach 2007-2014 uczelnie europejskie gościły 298 stypendystów z Nepalu, z czego kobiety stanowiły niecałe 17\% (Education, Audiovisual \& Culture Executive Agency b.r.).

Kontynuacją pracy badawczej na terenie Polski były badania terenowe w Nepalu w kwietniu 2017 roku, oparte na wcześniejszych kontaktach. Ich kluczowym elementem były ponowne wywiady pogłębione z absolwentami programu Erasmus Mundus, z którymi przez cały ten czas utrzymywałam kontakt za pomocą poczty elektronicznej i mediów społecznościowych. Przeprowadziłam 11 takich wywiadów - a zatem prawie z połową stypendystów, z którymi uprzednio rozmawiałam w Polsce. Dodatkowo, rozmawiałam z kilkorgiem studentów, którzy nigdy nie studiowali za granicą, a także z przedstawicielami kadry zarządzającej uczelni nepalskich i dyrektorami firm konsultingowych, zajmujących się rekrutacją młodych Nepalczyków na studia zagraniczne. W sumie było to 20 wywiadów i rozmów. 
W trakcie prowadzenia prac badawczych dążyłam do nawiązywania kontaktów i konsultowania się z osobami, których poglądy mogły wzbogacić badania, w tym z administratorami i pracownikami naukowymi opiekującymi się nepalskimi studentami i naukowcami podczas ich pobytu w Polsce, przedstawicielami uczelni partnerskich biorących udział w projektach i pracach Komisji Europejskiej.

Uczestniczyłam również w warsztatach i międzynarodowych konferencjach naukowych dotyczących spraw nepalskich, a także zapisałam się do dwóch organizacji skupiających badaczy zajmujących się Nepalem: Britain-Nepal Academic Council i Association for Nepal and Himalayan Studies. Pozwoliło mi to na bieżące śledzenie badań związanych z Nepalem, przegląd najświeższej literatury, stały kontakt z innymi badaczami o podobnych zainteresowaniach, jak również prezentację wyników moich prac.

Na każdym etapie badań istotnym elementem była obserwacja uczestnicząca: począwszy od pierwszych kontaktów z badanymi na uczelni, poprzez sytuacje formalne i nieformalne, rozmowy prywatne, po wywiady pogłębione i ponowne spotkania w Nepalu. W pełni zgadzam się ze stwierdzeniem Hammersley’a i Atkinsona mówiącym, że „(...) łączenie obserwacji uczestniczącej z prowadzeniem wywiadów niesie rozliczne korzyści”, ułatwia zrozumienie i interpretację danych, możerzucać nowe światło na przedmiot badań (1995, s. 138). Według autorów, wypowiedzi należy traktować ,jako zjawiska społecznezachodzące wkonkretnym kontekście i przezniego kształtowane” (Ibidem, s. 162). W przypadku moich badań, obserwacja uczestnicząca miała podwójny wymiar:

- interakcje z badanymi w sytuacjach niewywołanych przez bada$\mathrm{cza}^{5}$ (spotkania formalne i towarzyskie),

- interakcje wywołane przez badacza (wywiady pogłębione, konsultacje drogą e-mailową, luźne rozmowy dotyczące przedmiotu badań).

5 Silverman (2012, s. 183) pisze o danych wywołanych (nieistniejących bez interwencji badacza) i niewywołanych (występujących naturalnie, bez udziału badacza). 
Dodatkowe źródło danych stanowiły wszelkie dostępne źródła pisane: dokumenty formalne (na przykład artykuły dotyczące innych badań o podobnej tematyce), jak i nieformalne (takie jak pisemne relacje badanych); wewnętrzne (uczelni biorących udział w projekcie) i zewnętrzne, dostępne na stronach internetowych danych instytucji; zawierające surowe dane (na przykład statystyki GUS) oraz opracowania (na przykład raporty WENR, ICEF czy Banku Światowego).

Taka różnorodność źródeł pisanych pozwoliła na głębszą analizę danych i spojrzenie na problemy badawcze zarówno z zewnątrz, jaki od wewnątrz danego przedsięwzięcia; z punktu widzenia badanych, jak i badaczy; z perspektywy jednostki, jak i instytucji. Zastosowanie rozmaitych metod i źródeł danych miało na celu osiągnięcie efektu triangulacji, zapewnienie trafności wyników, ich pogłębienie i dotarcie do istotnych znaczeń.

„Szaleństwo wyjazdów zagranicznych" 6 w oczach studentów nepalskich

Dążenie młodych Nepalczyków do emigracji to ważny temat pojawiający się we wszystkich wywiadach i rozmowach. J ak zaobserwował jeden z badanych - student ekonomii na poziomie magisterskim - „w Nepalu, powiedziałbym, jesteśmy narodem migrantów. Ludziesą zwariowani na punkcie migracji poza granice Nepalu, do pracy, na studia” (W14). Inny stypendysta wyraził opinię, że to jest normalne - „każdy chce się wydostać z kraju w poszukiwaniu możliwości ” (W37).

Praktycznie wszyscy moi rozmówcy przed przyjazdem na stypendium do Polski podróżowali za granicę lub mieli w swoim otoczeniu takie osoby. Oczywiście najczęściej były to Indie: Nepal ma otwartą granicę z tym krajem i dla wielu Nepalczyków, szczególnie z Teraju, wyjazd do pracy lub do szkoły w Indiach jest czymś naturalnym.

Przykładem może być stypendysta z Biratnagar (miasta w południowowschodniej części kraju), który ukończył studia doktoranckie na najbliższej

${ }^{6}$ Cytat za jednym z badanych (W14). 
uczelni indyjskiej, a nie w sąsiednim Rampur czy w Kathmandu, ponieważ spodziewał się tam wyższego poziomu nauczania i miał dogodny dojazd (W03).

Prakash, wywodzący się z małej wioski w górach, opowiada o swoich doświadczeniach z dzieciństwa: ojciec wielokrotnie wyjeżdżał do Indii do pracy, a nim i jego rodzeństwem zajmowała się matka. Aby zademonstrować dobrą sytuację materialną rodziny, kazano mu nosić w obu uszach złote kolczyki (W12).

Z kolei Kavita, student telekomunikacji, w następujący sposób przedstawia tradycję wojskową w swojej rodzinie:

„Tak, członkowie mojej rodziny, mój ojciec, był oficerem nepalskiej armii. Bracia mojego ojca, moi wujowie, także byli oficerami w armii, mój dziadek był w indyjskim wojsku, nie wiem o swoim pradziadku, ale reszta moich pradziadków, pięciu braci, oni wszyscy byli w indyjskim wojsku." (W40)

Tak więc dla męskich członków jego rodziny wyjazdy do Indii czy też do innych krajów z tytułu służby w wojsku należały do porządku dziennego. Pytany student wspomina, że kiedy był dzieckiem, jego ojciec bardzo często przebywał poza domem. J uż samo pochodzenie respondenta zkasty Chetri ${ }^{7}$ wskazuje na przynależność do grupy, której w społeczeństwie nepalskim przypisuje się status wojowników. J ednakżesam Kavita niejest zainteresowany kontynuacją tradycji wojskowej. Ukończył studia w Kathmandu i swoją przyszłość wiąże raczej z tworzeniem lepszej infrastruktury telekomunikacyjnej w kraju (W40).

Pytani o doświadczenia międzynarodowe, moi rozmówcy podawali także liczne przykłady wyjazdów członków swojej rodziny i znajomych do StanówZjednoczonych, Australii, krajów Zatoki Perskiej, rzadziej do Europy. Wymieniane cele podróży to: praca, studia, staże, krótsze wyjazdy, na przykład na konferencje i spotkania.

7 Według Johna Whelptona(2005, s. 31), kasta Chetri pochodzi od kasty Khasas. Jest to uprzywilejowana kasta dwukrotnie urodzonych, wywodzących się z gór. Podobnie jak wyżej ulokowana kasta Thakuris (wywodząca się z indyjskiego rodu Rajput), Chetri uważani są za klasę wojowników w klasycznej hierarchii (varna). 
Wśród młodzieży wywodzącej się z klasy średniej rozpowszechnił się trend wyjeżdżania na studia zagraniczne - „tylko aby studiować poza Nepalem" (W40). Amita, doktorantka na Uniwersytecie Oksfordzkim, twierdzi, że na skutek tej mody, ci, którym powiodło się na uczelniach zagranicznych stanowią wzór do naśladowania dla innych młodych $\mathrm{Ne}$ palczyków (W35). Rashmi, studentka zarządzania na uczelni warszawskiej, opisuje ten trend następująco:

„Kiedy skończyłam studia licencjackie, poszukiwałam możliwości kontynuowania studiów, wiesz, w tak jakby, w innej części świata. Chciałam studiować winnej części świata, to było takie moje marzenie, aby studiować, aby poznać świat. Tak więc szukałam jakiejś dobrej instytucji lub organizacji, która mogłaby mi zaoferować dobre wykształcenie i stypendium [...]. W Nepalu jest obecnie trend, aby zdobywać wykształcenie wyższe w innych częściach świata, zazwyczaj w Stanach Zjednoczonych, Wielkiej Brytanii i Australii." (W08)

Według Amity, tendencja ta znacznie wzrosła w ciągu ostatnich dziesięciu lat, po zakończeniu wojny. Podkreśla, żezmieniły się przepisy emigracyjne, szeroki dostęp do Internetu i mediów społecznościowych pozwolił na sprawną komunikację, a dodatkowo, w Nepalu powstały liczne agencje, firmy doradcze i pośredniczące, które pomagają zainteresowanym znaleźć odpowiednie studia poza granicami kraju.

Ponadto wyjazdom sprzyjają działania instytucji w krajach goszczących i nacisk na umiędzynarodowienie i komercjalizację szkolnictwa wyższego. Amicie dobrze znana jest sytuacja w Wielkiej Brytanii: powstawały uczelnie, które przyjmowały studentów z krajów rozwijających się na płatne studia, stawiając bardzo niewielkie wymagania akademickie. Studenci mogli swobodnie pracować, a naukę stawiali na dalszym planie. Na koniec wszyscy otrzymywali dyplom ukończenia studiów. Dla Nepalczyków dyplom wydany przez jakąkolwiek uczelnię brytyjską był bardzo cenny - bez względu na jakość nauczania i reputację danej szkoły. 
Według mojej rozmówczyni, w roku 2011 rząd brytyjski zamknął te uczelnie (W35). Nie zmieniło to jednak znacząco trendu wśród Nepalczyków, aby ubiegać się o studia w Wielkiej Brytanii. Rup, student ekonomii, od dzieciństwa marzył o nauce na Wyspach Brytyjskich. Przygotowywał się do tego od, jak twierdzi, dziesiątego roku życia: uczył się w brytyjskiej szkole z internatem w Kathmandu, zdał egzamin IELTS (zjęzyka angielskiego), ukończył studia licencjackie w Indiach z bardzo dobrymi wynikami. Utrzymuje, że studia w Nepalu obniżyłyby jego szanse na dostanie się na kolejne studia w Wielkiej Brytanii. Po otrzymaniu dyplomu, wysłał dokumenty do czterech uczelni brytyjskich i z trzech otrzymał pozytywną odpowiedź. Teraz czeka go decyzja, którą z nich wybrać. Większość jego kolegów ze szkoły średniej studiuje za granicą - szacuje, że jest to około 80\%. Także jego kuzyni pracują lub studiują w Stanach Zjednoczonych i w Wielkiej Brytanii. J ego rodzice sami studiowali za granicą i mocno wspierają go w dążeniu do celu, jakim jest kontynuacja nauki w Europie (W46).

Inni badani także oceniają, że większość ich kolegów i koleżanek ze studiów wyjechała za granicę (podają liczby w przedziale 60-90\%). Ta determinacja spowodowana jest licznymi problemami dotykającymi Nepal: społecznymi, politycznymi, ekonomicznymi, ekologicznymi. J ak twierdzi jeden ze studentów, wystarczy spojrzeć za okno: tutaj brak nawet świeżego powietrza (W14).

Bishal - pracownik naukowy w dziedzinie stosunków międzynarodowych - dostrzega istotne czynniki psychologiczne, ekonomiczne i życiowe, które warunkują tak liczne wyjazdy młodych Nepalczyków: prestiż, szansa na lepszą pracę i sytuację materialną, możliwość zdobycia doświadczenia życiowego i zawodowego. Przeważają jednak czynniki przyciągające do krajów goszczących: stypendia, lepsze warunki nauki, wyższy standard życia, praca (W43). Pojawiają się głosy, że tak naprawdę młodzi nie są zainteresowani pozostaniem w Nepalu (W09). 
Studenci zagraniczni czy migranci edukacyjni?

W swoim artykule na temat studentów nepalskich w Danii, Karen Valentin (2012) rozróżniła studentów zagranicznych, przyjeżdżających do kraju goszczącego na czas trwania studiów, oraz migrantów edukacyjnych - czyli osoby, które dążą do zdobycia dyplomu uczelni zagranicznej, a jednocześnie ubiegają się o kartę pobytu, podejmują pracę i wiążą swoją przyszłość z życiem na emigracji.

W moich rozmowach ze studentami nepalskimi w Polsce również pojawiało się pytanie o to, czy młodzi Nepalczycy masowo wyjeżdżający na studia zagraniczne, w przyszłości wrócą do kraju ojczystego. Według Deepaka, zrobią to tylko nieliczni - ci, którzy szczególnie troszczą się o przyszłość kraju i mają poczucie misji (W09).

Rashmi także wyraża sceptyczną opinię:

„Teraz sprawy nadal mają się źle, Nepal jest bardzo biedny i w sektorze edukacji nadal są podstawowe problemy związane z dostawą wody i zaspokojeniem podstawowych potrzeb. Z powodu tych niedoborów i niezaspokojenia podstawowych potrzeb większość młodziėzy wyjeżdża do obcych krajów. W większości do USA i oni nie chcą wracać do kraju. Oni nie chcą służyć krajowi. To jest sprawa, która mnie boli. Bo my musimy to robić, ale nie ma dobrych kandydatów aby to robić, aby pracować dla kraju". (W08)

Kilkakrotnie słyszałam, że ci, którzy otrzymują stypendia, przeważnie po ich zakończeniu wracają do ojczyzny. Natomiast ci, którzy muszą podejmować pracę lub spłacać pożyczki zaciągnięte na studia za granicą, nie mogą sobie na to pozwolić, ponieważ w Nepalu nie byliby w stanie zarobic tak wysokiej kwoty. Według Baruna, pracownika naukowego i dyrektora uczelni prywatnej, w powyższych przypadkach proporcje powrotów wynoszą odpowiednio 90\% do 10\% i 10\% do 90\% (W38).

Wpisują się w to badane przez mnie przypadki: stypendyści Erasmus Mundus praktycznie wszyscy wrócili do Nepalu po zakończeniu wizyty 
w Polsce. W kolejnych latach uzyskałam informacje, że tylko troje z nich wyjechało za granicę w celach naukowych lub zawodowych. W innej sytuacji był Netra: studiował i pracował w Stanach Zjednoczonych, jednakże po 7 latach zdecydował się wrócić z powodów rodzinnych. Musi zająć się rodzicami, ponieważ w Nepalu ubezpieczeniem osób starszych są ich dzieci. Zaobserwowal, że 7 lat pobytu na obczyźnie to bardzo często cezura wyznaczającą datę powrotu do kraju lub pozostania za granicą na stałe: daje to czas na ukończenie studiów i zdobycie doświadczenia zawodowego. Po tym czasie należałoby już ubiegać się o stały pobyt w kraju goszczącym.

Nic nie wskazuje na to, aby ten trend czy też „moda” na wyjazdy zagraniczne w najbliższym czasie zaniknęła. Po katastrofalnym trzęsieniu ziemi w kwietniu 2015 roku skala wyjazdów, lub - słowami Sharmy (2011) - „exodus” młodych Nepalczyków jeszcze wzrósł. W Nepalu funkcjonuje ponad 1000 agencji konsultingowych, które obiecują możliwość wyjazdu na studia do krajów wysoko rozwiniętych, do atrakcyjnych miejsc znanych z filmów i kultury popularnej. Każda z tych firm otrzymuje kilkaset wniosków rocznie i znaczną ich część rozpatruje pozytywnie. J eden z rekruterów oszacował, że co roku wysyła do uczelni zagranicznych około 200 studentów. Większość z nich nie myśli o powrocie do Nepalu. Zdaniem Hrithika - magistranta na Wydziale Ekonomii - wiele musiałby się wydarzyć, aby ta sytuacja uległa zmianie, szczególnie jeżeli chodzi o rozwój ekonomiczny kraju i jakość życia:

„Nie sądzę, że będzie inaczej, może tylko się zmieni, kiedy poczynimy jakieś kroki wkierunku rozwoju kraju. Tylko wtedy to się może zatrzymać.

W każdym innym przypadku nie widzę możliwości, aby zatrzymać falę ludzi opuszczających kraj”. (W37).

Nic więc dziwnego, że w obliczu tych zjawisk młodzi Nepalczycy poszukują coraz to nowych kierunków migracji, także do krajów, które tradycyjnie nie cieszyły się zainteresowaniem. 
Nowe kierunki migracji

Według badanych, najczęściej wybierane kierunki wyjazdów w celach edukacyjnych to: Australia, Stany Zjednoczone, J aponia, Wielka Brytania, kraje skandynawskie. Pozostałe kraje europejskie, w tym Polska, nie cieszą się aż taką popularnością i młodzi Nepalczycy nie mają zbyt wiele wiedzy na ich temat. Przytoczę tu słowa jednej ze stypendystek:

„Prawdę mówiąc, studiowanie w Polsce nie jest zbyt popularne w Nepalu. Zazwyczaj studenci wyjeżdżają do Stanów, Australii i zanim przyjechałam do Polski słyszałam o Polsce tylko przy okazji zawodów, jak chociażby Olimpiada lub inne zawody, wiedziałam, że Polska bierze wnich udział. Wiedziałam tylko, że Polskajest krajem w Europie, w pobliżu Rosji, Ukrainy, że ma komunistyczną przeszłość. Tyle wiedziałam o Polsce przed przyjazdem". (W02)

Z drugiej jednak strony, jak powiedział student ekonomii Hem, nepalska młodzież robi wszystko, aby wyjechać z kraju i nie odrzuca żadnej możliwości emigracji, zarówno wcelach edukacyjnych, jaki zawodowych (W14). J eśli więc pojawia się szansa ukończenia studiówi zdobycia stypendium wjakimkolwiek kraju wysoko rozwiniętym, chętnie z niej korzystają.

Oto jak o wyborze studiów w Polsce opowiadał Deepak:

„Ukończyłem studia magisterskie tutaj w Nepalu i szukałem dobrego stypendium za granicą. Dowiedziałem się o programie stypendialnym Erasmus Mundus, napisałem do koordynatora, odpisał mi od razu, więc złożyłem wniosek. Chciałem studiować stosunki międzynarodowe i ten program był świetny. Właściwie dowiedziałem się o programie od swojego profesora w Conflict, Peace and Development Studies. Powiedział mi, że jest taki program i się zgłosiłem”. (W09)

A zatem zjednej strony istotnym czynnikiem była rekomendacja znajomego profesora, a z drugiej - interesujący program studiówi możliwość uzyskania wsparcia finansowego. W obliczu takich możliwości zaintere- 
sowanie znajdują także kierunki mniej oczywiste, takie jak kraje bałtyckie czy Polska. Na podstawie wypowiedzi badanych można wywnioskować, że Polska została wybrana przez nich raczej przypadkowo: zależało im na możliwości zdobycia dyplomu z kraju należącego do Unii Europejskiej i uzyskaniu stypendium. J ednocześnie jednak przewidywali, że wyjazd do kraju mniej popularnego wśród Nepalczyków będzie wyróżniał ich zarówno na rynku pracy, jak i w sytuacjach społecznych.

\section{Podsumowanie}

J ak dowodzą przytoczone badania, kultura migracji jest niezwyklesilnie zakorzeniona w społeczeństwie nepalskim. Znajduje to odzwierciedlenie zarówno w wyjazdach w celach zarobkowych, jak i edukacyjnych. Po rewolucji Maoistów skala emigracji z Nepalu dramatycznie wzrosła. Na ten stan rzeczy wpłynęło wiele czynników wewnętrznych i zewnętrznych. Do czynników wewnętrznych możemy zaliczyć niepewną sytuację polityczną w Nepalu, niestabilność gospodarki, niskąjakość kształcenia i upolitycznienie uniwersytetów, brak dopasowania programównauczania do wymogów rynku pracy, brak perspektyw na zdobycie odpowiedniej pracy po ukończeniu studiów, komercjalizację szkolnictwa, uproszczenie przepisów emigracyjnych, tworzeniesię nowej klasy średniej. W tym samym czasie, niektóre kraje w Azji i na Bliskim Wschodzie przeżyły znaczny wzrost gospodarczy (na przykład Indie, Malezja, kraje Zatoki Perskiej), co zachęciło Nepalczyków do migracji w tych kierunkach.

Zewnętrzne czynniki sprzyjające mobilności akademickiej to tworzenie programów nauczania przeznaczonych dla studentów zagranicznych w krajach goszczących, powstawanie licznych programów stypendialnych, nacisk na umiędzynarodowienie uniwersytetów, rozwój komunikacji globalnej i mediów społecznościowych.

Wśród nepalskiej młodzieży poszukującej możliwości zdobycia wykształcenia za granicą najpopularniejsze kierunki to Australia, J aponia, 
Indie, Ameryka Północna, Wielka Brytania. Kraje kontynentalnej Europy cieszą się nieco mniejszym zainteresowaniem, ale i tu w ostatnich latach można zaobserwować wzmożony napływ studentów nepalskich, także do uczelni polskich. Można wywnioskować, że młodzi Nepalczycy poszukują coraz to nowych kierunków wyjazdów na studia zagraniczne. Należy podkreślić, że migracja w celach akademickich jest mocno osadzona w istniejącej w Nepalu kulturze migracji oraz w powiązanych z nią uwarunkowaniach historycznych i kulturowych. Jak puentuje Valentin (2014), indywidualne ścieżki edukacyjne mają swoje podłoże w szerszych praktykach migracyjnych.

Literatura

Ali S. (2007), Go West Young Man: The Culture of Migration among Muslims in Hyderabad, India, "Journal of Ethnic and Migration Studies" Vol. 33, No. 1

allscholarshipdotnet (2016), Scholarships for Nepalese Students 2016, Allscholarship.net, http://www.allscholarship.net/scholarships-for -nepalese-students-2016/

Bhadra Ch. (2007), International Labour Migration of Nepalese

Women: the Impact of their Remittances on Poverty Reduction, "Asia-Pacific Research and Training Network on Trade Working Paper Series" No 44

Bhattarai K. (2011), Brain Gain (Drain), Immigration and Global Network: Nepalese Students in the UK., "International J ournal of Economic Policy in Emerging Economies" Vol. 4, Iss. 4, doi: 10.1504/IJ EPEE.2011.043309

Borenovic Dilas D., Cui J ., Trines S. (2018), Education in Nepal, World Education News + Reviews, https:// wenr.wes.org/2018/04/ education-innepal 
Bruslé T. (2009-2010), Nepalese migrations: Introduction, "European Bulletin of Himalayan Research" Vol. 35-36, http:// himalaya.socanth. cam.ac.uk/ collections/journals/ ebhr/ pdf/EBHR_35\&36_02.pdf

Clark N. (2013), Academic Mobility and the Education System of Nepal, http:// www.hamroschool.com/ academic-mobility-and-theeducation-system-of-nepal/

Cohen J .H. (2004), The Culture of Migration in Southern Mexico, University of Texas Press, Austin

Education, Audiovisual \& Culture Executive Agency (b.r.), Erasmus Mundus Action 2, Scholarship Holders' Impact Survey, Results, Brussels, https:// eacea.ec.europa.eu/sites/ eacea-site/ files/ em_sch olarship_holder_impact_survey_results_en.pdf

e-Governance Academy (b.r.), Nepal e-Governance enthusiasts to study Estonian e-governance, https:// ega.ee/news/nepal-e-gover nance-enthusiasts-to-study-estonian-e-governance/

Fafchamps M., Shilpi F. (2013), Determinants of the Choice of Migration Destination, "Oxford Bulletin of Economics and Statistics" Vol. 75, Iss. 3

Government of Nepal, Ministry of Labour and Employment, Department of Foreign Employment (2014), Labour Migration for Employment. A Status Report for Nepal: 2013/2014, Katmandu, https:// asiafoundation.org/ resources/ pdfs/ MigrationReportbyGovernmentofNepal.pdf.

Gurung Y.B. (2008), Migration from Rural Nepal. A Social Exclusion Framework, Central Department of Population Studies, Tribhivan University, Kirtipur

GUS (2018), Zezwolenia na pracę cudzoziemców $w$ Polsce $w 2017$ r., https:// stat.gov.pl/ obszary-tematyczne/ rynek-pracy/ opracowania/ zezwolenia-na-prace-cudzoziemcow-w-polsce-w-2017-r-, 18,1.html Hammersley M., Atkinson P. (2000), Metody badań terenowych, Zysk i S-ka, Poznań 
ICEF (2015a), Nepal emerging as an important growth market for international education, "TCEF Monitor", http://monitor.icef.com/ 2015/ 12/ nepal-emerging-as-an-important-growth-market-for-international-education/

ICEF (2015b), German language study on the rise worldwide, "ICEF Monitor", http:/ / monitor.icef.com/2015/ 04/ german-language-stud y-on-the-rise-worldwide/

ICEF (2015c), Finnish universities facing big budget cuts; fees for non$E U$ students back on the table, "ICEF Monitor", http://monitor. icef.com/ 2015/ 06/ finnish-universities-facing-big-budget-cuts-feesfor-non-eu-students-back-on-the-table/

ICEF (2015d), International student mobility picking up in Norway while major reforms take shape, „ICEF Monitor”, http://monitor.icef.com/ 2015/ 04/ international-student-mobility-picking-upin-norway-while-major-reforms-take-shape/

ICEF (2016), Finland introduces university tuition fees for non-EU students, "ICEF Monitor", http://monitor.icef.com/2016/01/ finland -introduces-university-tuition-fees-for-non-eu-students/

Kandel W. Massey D. (2002), The culture of Mexican migration: a theoretical and empirical analysis, "Social Forces” Vol. 80, Iss. 3

Kansakar V.B.S. (2003), International Migration and Citizenship in Nepal, (w:), Population Monograph of Nepal, Vol. 2, Government of Nepal, National Planning Commission Secretariat, Central Bureau of Statistics, Kathmandu, http://old.cbs.gov.np/sectoral_statistics/ population/population_monograph_nepal_2003_all

Katiwada Y. (2008), Brain Drain, „Nepali Times” Iss. 417, 18 September Kharel D. (2016), From Lahures to Global Cooks: Network Migration from the Western Hills of Nepal to Japan, "Social Science Japan Journal" Vol. 19, Iss. 2, DOI: 10.1093/ssjj/jyw033 
Lohani S. (2016), Is going abroad the only answer?, "The Himalayan Times" December 21, https://thehimalayantimes.com/ education/ going-study-abroad-answer/

Seddon D. (2005), Nepal's Dependence on Exporting Labor, Migration Policy Institute, Washington- Brussels, https:// www.migrationpolicy.org/ article/ nepals-dependence-exporting-labor

SharmaJ .R. (2011), Culture of Migration in the Middle Hills of Nepal, "Edinburgh Research Explorer", The University of Edinburgh, Edinburgh, http://lib.icimod.org/record/26975/files/c_attachment_767_6003.pdf Silverman D. (2012), Interpretacja danych jakościowych, Wydawnictwo Naukowe PWN, Warszawa

Singh M. (2005), Student mobility, "The Himalayan Times” April 13, https:// thehimalayantimes.com/ opinion/ student-mobility/

UNESCO Institute of Statistics (2019), Nepal, General Information, http:/ / uis.unesco.org/ country/ NP

Uppsala Universitet (b.r.), We welcome students from Nepal!, http:// www.uu.se/ en/ admissions/ master/ countries/ nepal/

Valentin K. (2005) Schooled for the Future? Educational Policy and Everyday Life Among Urban Squatters in Nepal, Information Age Publishing Inc., Greenwich

Valentin K. (2012), Caught between internationalization and immigration. The case of Nelpalese students in Denmark, "Learning and Teaching" Vol. 5, Iss. 3

Valentin K. (2014), Transnational education and the remaking of social identity: Nepalese student migration to Denmark, Aarhus University, Aarhus

Whelpton J . (2005), A History of Nepal, Cambridge University Press, Cambridge 